\title{
Perbedaan Reliabilitas Pola Sidik Bibir dan Pola Ruga Palatal dalam Penentuan Jenis Kelamin
}

\author{
Okky Marita Ardy*1, Susy Kristiani ${ }^{2}$, Mieke Sylvia M.A.R ${ }^{3}$ \\ ${ }^{1,2}$ Prodi S2 Ilmu Forensik Sekolah Pascasarjana Universitas Airlangga \\ ${ }^{3}$ Departemen Odontologi Forensik, FKG UNAIR, Surabaya \\ e-mail: *1.
}

\begin{abstract}
Abstrak
Penentuan jenis kelamin adalah salah satu faktor utama yang digunakan untuk membantu identifikasi individu, membantu dalam pembentukan profil biologis dari sisa-sisa kerangka dan gigi. Masalah akan timbul dengan berbagai variasi tingkat kesulitan dimana tindakan identifikasi termudah dan sederhana yaitu secara visual tidak lagi dapat digunakan. Identifikasi forensik pada orang hidup atau meninggal dapat menggunakan teknik yang berbeda yang melibatkan berbagai metode penunjang seperti cheiloscopy dan palatoscopy yang unik dan menunjukkan variasi individu. Meskipun ada banyak studi penelitian dengan dua metode tersebut, tetapi studi yang membandingkan dua metode bersama-sama terhadap reliabilitas atau kehandalan dalam penentuan jenis kelamin minimal. Tujuan penelitian ingin mengetahui perbedaan reliabilitas pola sidik bibir dan pola ruga palatal dalam penentuan jenis kelamin. Penelitian ini menggunakan 68 sampel (34 pria dan 34 wanita) mahasiswa Kedokteran Gigi Universitas Airlangga Surabaya kisaran usia 21-30 tahun dengan mengambil sidik bibir dengan menggunakan lipstik dan pembuatan cetakan ruga palatal dengan bahan cetak irreversible hydrocolloid. Analisis reliabilitas pola sidik bibir dan ruga palatal menggunakan Koefisien Cohen's Kappa. Reliabilitas pola sidik bibir yaitu $K=0,834$ dengan kategori sangat baik, sedangkan reliabilitas pola ruga palatal yaitu $K=0,593$ dengan kategori sedang. Analisis Chi-Square pola sidik bibir didapatkan nilai p-value sebesar 0,002, sedangkan pola ruga palatal didapatkan nilai p-value sebesar 0,464. Reliabilitas pola sidik bibir lebih tinggi daripada reliabilitas pola ruga palatal dalam penentuan jenis kelamin. Terdapat hubungan antara pola sidik bibir dengan jenis kelamin, tetapi tidak untuk pola ruga palatal.
\end{abstract}

Kata kunci-sidik bibir, ruga palatal, reliabilitas, penentuan jenis kelamin

\begin{abstract}
Determination of sex is one of the main factors used to aid in the identification of individuals, assist in the formation of biological profile of the remains of the skeleton and teeth. Problems will arise with a variety of difficulty levels where the easiest and simple identification is visually no longer be used. Forensic identification of the lives or dies person can use different techniques that involve various methods of support such as cheiloscopy and palatoscopy which are unique and show individual variation. Although there are many studies with these two methods, but a study comparing the two methods together to the reliability in the determining sex is minimal. This aim of this study was to know the distinction of reliability of lip prints pattern and palatal rugae pattern in sex determination. This study using 68 samples (34 males and 34 females) students of Dentistry, Airlangga University with age range of 21-30 years old, by taking lip print with lipstick and taking palatal rugae pattern with irreversible hydrocolloid material. Reliability of lip prints and palatal rugae were assessed using Cohen's Kappa coefficient. Reliability of lip prints pattern is $K=0,834$ with very good category, while reliability of palatal
\end{abstract}

JBP Vol. 17, No. 3, Desember 2015-Okky Marita Ardy 
Jurnal Biosains Pascasarjana Vol. 17 (2015) pp

(C) (2015) Program Pascasarjana Universitas Airlangga, Indonesia

rugae pattern is $K=0,593$ in the medium category. Analysis Chi-Square test of the lip prints pattern obtained p-value of 0,002, while the palatal rugae pattern obtained p-value of 0,464. The 
result showed the reliability of lip prints pattern is higher than the reliability of rugae palatal pattern in determining of sex. There is a relationship between lip prints pattern with sex, but not for palatal rugae pattern.

\section{Keywords—lip prints, palatal rugae, reliability, sex determination}

\section{PENDAHULUAN}

Odontologi forensik memainkan peran penting dalam penentuan jenis kelamin seperti pada korban bencana massal atau tindakan kriminal (Rai et al., 2013). Penentuan jenis kelamin adalah salah satu faktor utama yang digunakan untuk membantu identifikasi individu, membantu dalam pembentukan profil biologis dari sisa-sisa kerangka dan gigi dan juga membantu dalam rekonstruksi wajah mayat yang tidak dikenal (Nagalaxmi et al., 2014).

Identifikasi positif dari seseorang bisa sangat sulit dalam berbagai kasus perdata, pidana, dan bencana massal. Kejadian bencana massal seperti kecelakaan kapal tenggelam, pesawat jatuh, kasus terorisme dan tindakan kriminal akan menghasilkan keadaan jenazah yang mungkin dapat intak, separuh intak, membusuk, tepisah berfragmen-fragmen, terbakar menjadi abu, separuh terbakar, terkubur ataupun kombinasi dari bermacammacam keadaan (Prawestiningtyas dkk., 2009).

Masalah akan timbul dengan berbagai variasi tingkat kesulitan dimana tindakan identifikasi termudah dan sederhana yaitu secara visual tidak lagi dapat digunakan. Perbandingan sidik jari, DNA, dan dental record merupakan metode primer yang digunakan dalam proses identifikasi (Saraf et al., 2011, Kapoor et al., 2015). Beberapa metode sekunder atau penunjang seperti yang digunakan dalam odontologi forensik yaitu cheiloscopy dan palatoscopy yang mampu memberikan hasil yang relatif handal (Nagalaxmi et al., 2014). Perbedaan terkait dengan metode-metode tersebut harus dipertimbangkan dengan hati-hati untuk membuat odontologi forensik lebih akurat, dapat diandalkan, dan digunakan dalam penyelidikan (Kavitha et al., 2009).
Identifikasi korban maupun pelaku juga dapat dilakukan melalui benda-benda yang ditemukan pada TKP seperti bercak darah, bercak sperma, air liur, pakaian, perhiasan, telepon genggam, bahkan gigi tiruan. Tidak tertutup kemungkinan pada kasus-kasus perkosaan dan perampokan, pelaku atau korban meninggalkan jejak berupa sidik bibir pada makanan, alat makan seperti gelas, cangkir ataupun benda lainnya seperti puntung rokok (Dongarwar et al., 2013).

Sidik bibir merupakan pola berupa celah atau fisur yang terdapat pada permukaan mukosa bibir. Pemeriksaan sidik bibir dikenal sebagai cheiloscopy. Pentingnya cheiloscopy ini terkait dengan fakta bahwa sidik bibir unik untuk satu orang, termasuk pada kembar monozigot, seperti sidik jari dan ruga palatal (Kapoor et al., 2015). Sidik bibir yang terdapat pada objek yang ditemukan pada TKP dapat dibandingkan dengan sidik bibir tersangka ataupun korban, sehingga hasil analis sidik bibir tersebut dapat dijadikan sebagai salah satu alat bukti untuk kepentingan identifikasi (Dongarwar et al., 2013). Sidik bibir pada jenazah harus dapat diperoleh dalam waktu 24 jam dari saat kematian untuk mencegah data yang salah oleh karena perubahan post mortem bibir (Kavitha et al., 2009).

Ketidak matangan bibir di usia yang lebih muda, pola anatomi dan tonisitas yang berkurang pada usia yang lebih tua dapat berpengaruh besar terhadap pola sidik bibir. Pada penelitian ini menggunakan subyek dengan kisaran usia 21-30 tahun karena sesuai penelitian Randhawa et al., (2011) yang menunjukkan perbedaan pola sidik bibir yang signifikan pada usia 21-40 tahun. Penelitian sidik bibir oleh Kapoor et al., (2015) pada populasi Marathi di India Tengah ditemukan perbedaan yang signifikan antara pola sidik bibir pria dan wanita. Hal ini sama dengan penelitian Kautilya et al., (2013) dengan tipe III ditemukan paling dominan pada pria, 
sedangkan tipe I paling dominan pada wanita. Penelitian yang dilakukan oleh Devi et al., (2015) di India tidak menemukan perbedaan yang signifikan dalam pola sidik bibir berdasarkan jenis kelamin.

Palatoscopy (palatal rugoscopy) mengacu pada studi tentang ruga palatal dalam penentuan identitas seseorang (Indira et al., 2012, Azab et al., 2015). Ruga palatal, seperti sidik jari, tidak berubah selama kehidupan individu, terlindung dari trauma dan suhu tinggi karena posisinya yang terletak di dalam rongga mulut dan dilindungi oleh bibir, pipi, lidah, gigi dan tulang. Ruga palatal juga memiliki ketahanan yang cukup baik terhadap perubahan dari penyakit, trauma, zat kimia, suhu tinggi, dan dekomposisi. Ruga palatal dapat bertahan dari dekomposisi hingga 7 hari setelah kematian (Rajan et al., 2013).

Metode identifikasi pola ruga palatal cukup sering menggunakan klasifikasi Thomas dan Kotze dan Kapali yang meliputi jumlah, panjang, bentuk, dan unifikasi atau penyatuan ruga palatal. Karakteristik kualitatif seperti bentuk, arah dan unifikasi tetap stabil sepanjang hidup (Saraf et al., 2011). Penelitian Barath et al., (2011) dari populasi Andhra di pesisir India mengungkapkan perbedaan unifikasi ruga palatal antara pria dan wanita yang ditemukan signifikan, tetapi tidak untuk jumlah ruga palatal. Perbedaan signifikan juga ditemukan antara pria dan wanita yang terlihat pada pola ruga palatal baik bentuk dan jumlah dalam penelitian oleh Saraf et al., (2011) di India dan Fahmi et al., (2001) di Mesir.

Identifikasi forensik pada orang hidup atau meninggal dapat menggunakan teknik yang berbeda yang melibatkan berbagai metode penunjang seperti cheiloscopy dan palatoscopy yang unik dan menunjukkan variasi individu. Meskipun ada banyak studi penelitian dengan dua metode tersebut, tetapi studi yang membandingkan dua metode bersama-sama terhadap reliabilitas atau kehandalan dalam penentuan jenis kelamin minimal. Pada penelitian Nagalaxmi et al., (2014) didapatkan hasil yang sama dengan penelitian Sharma et al., (2009) pada mahasiswa Kedokteran Gigi Meerut, di India sebanyak 50 pria dan 50 wanita yaitu ditemukan perbedaan signifikan pada pola sidik bibir pada pria dan wanita, sementara tidak ada perbedaan signifikan pada pola ruga palatal. Penelitian Nagalaxmi et al., (2014) dengan 60 sampel pasien usia 20-30 tahun dari Departemen Oral Medicine dan Radiologi, Kedokteran Gigi India menunjukkan keunikan sidik bibir dan pola ruga palatal dengan cheiloscopy menunjukkan sensitivitas $81,7 \%$ memberikan prediksi jenis kelamin lebih handal dari palatoscopy.

Dari uraian masalah diatas penulis ingin mengetahui perbedaan reliabilitas pola sidik bibir dan pola ruga palatal dalam penentuan jenis kelamin pada mahasiswa Kedokteran Gigi Universitas Airlangga.

\section{Sidik Bibir dan Ruga Palatal}

\subsection{Klasifikasi dan Metode Pengambilan Sidik Bibir}

Cheiloscopy (dari kata Yunani cheilos = bibir, skopein = melihat) adalah studi tentang pola yang dibentuk oleh celah atau fisur dan alur dari mukosa labial (sulci labiorum) membentuk pola karakteristik yang digambarkan sebagai sidik bibir (Senn et al., 2013, Kaul et al., 2015).

Fenomena biologis sistem alur pada bagian merah dari bibir manusia pertama kali dicatat oleh antropolog. R Fischer adalah orang pertama yang menggambarkan sidik bibir pada tahun 1902. Penggunaan sidik bibir dalam identifikasi personal dan kriminalisasi pertama direkomendasikan di Perancis oleh Edmond Locard (Randhawa et al., 2011, Malik et al., 2011).

Tahun 1950 Synder adalah orang pertama yang menyarankan untuk menggunakan sidik bibir untuk identifikasi. Dia telah melakukan investigasi dalam kecelakaan lalu lintas dan menetapkan bahwa karakteristik bibir yang dibentuk oleh alur bibir adalah karakteristik individual yang khas seperti karakteristik sidik jari. Antara tahun 1968 dan 1971, dua ilmuwan Jepang (Suzuki dan Tsuchihashi 1970) meneliti 1.364 orang pada Departemen Odontologi Forensik di Universitas Tokyo. Berdasarkan penelitian ini, 
disimpulkan bahwa susunan garis-garis pada bagian merah dari bibir manusia adalah individual dan unik untuk setiap manusia. (Rai et al., 2013).

Tahun 1974, Suzuki dan Tschihashi menegaskan bahwa sidik bibir dari bibir yang mengalami trauma adalah sama setelah mengalami proses penyembuhan (Nagalaxmi et al., 2014). Tahun 1981 dilaporkan dalam buku Outline of Forensic Dentistry oleh Cottone, cheiloscopy merupakan salah satu teknik khusus yang digunakan untuk identifikasi personal (Dineshshankar et al., 2013). Selama tahun 1985-1997, teknik cheiloscopy digunakan dalam 85 kasus, termasuk 65 kasus perampokan, 15 kasus pembunuhan, dan 5 kasus penyerangan. Dalam 34 kasus identifikasi positif, yang berarti bahwa teknik cheiloscopy sama nilainya dengan jenis bukti forensik yang lain. Hal ini juga termasuk dalam bukti yang diajukan di pengadilan (Rai et al., 2013).

Dr. Martins Santos pada tahun 1960 mengusulkan bahwa karakteristik bibir ini dapat digunakan dalam identifikasi personal dan merancang sistem yang sederhana untuk mengklasifikasikan sidik bibir. Pada tahun 1967, Suzuki membuat detail penelitian pengukuran bibir, penggunaan dan warna pemerah bibir dan metode pengambilan untuk memperoleh data yang berguna untuk aplikasi forensik. Kemudian pada tahun 1971 Suzuki dan Tsuchihashi, melakukan penelitian dan mereka menyusun klasifikasi mereka sendiri (Dineshshankar et al., 2013).

Sidik bibir dapat diklasifikasikan menggunakan beberapa metode antara lain Klasifikasi Martín Santos (1967) yang membagi alur bibir menjadi dua kelompok: (1) simple, ketika alur dibentuk oleh satu elemen; elemen ini bisa dalam bentuk straight line, curve, angular, atau sinusoidal; (2) compound, ketika alur dibentuk oleh beberapa elemen, bisa dalam bentuk bifurcated, trifurcated, atau anomalous.

Klasifikasi Renaud (1973) yang membagi bibir dalam dua bagian (kiri dan kanan), dan setiap bentuk alurnya disimbolkan dalam bentuk huruf. Menurut rumus Renaud, huruf kapital digunakan untuk menggambarkan bibir atas sisi kiri (L) dan sisi kanan (R), dan huruf kecil mengklasifikasikan setiap alur. Di bibir bawah, hal itu dilakukan sebaliknya, menggunakan huruf kapital untuk mengklasifikasikan alur, dan huruf kecil untuk memisahkan sisi kiri dan sisi kanan.

Klasifikasi yang sering digunakan adalah klasifikasi Suzuki and Tsuchihashi (1971) karena memiliki deskripsi pola yang jelas dan mudah diinterpretasikan. Metode ini berdasarkan perbedaan enam tipe alur (Rotzsher et al., 2014) :

a. Type I: alur vertikal pada seluruh bibir

b. Type Ia: alur vertikal sebagian pada bibir

c. Type II: alur bercabang

d. Type III: alur menyilang

e. Type IV: alur seperti jala atau jaring

f. Type V: lainnya

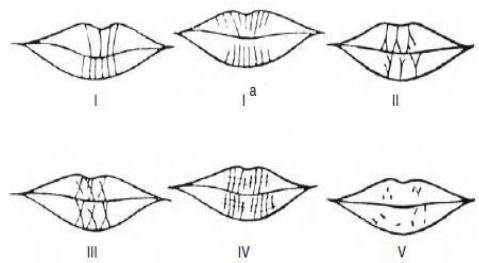

Gambar 1. Klasifikasi sidik bibir (Suzuki and Tsuchihashi 1971) (Rotzsher et al., 2014)

Pada kasus kriminal, ditemukannya sidik bibir pada suatu benda menunjukkan bahwa bibir seseorang telah menyentuh benda lain yang dapat dikaitkan dengan kemungkinan orang tersebut terkait dengan kasus kriminal tersebut. Bibir tanpa lipstik yang menyentuh benda lain dapat meninggalkan bekas atau jejas pada benda yang disentuhnya namun tidak dapat terlihat secara kasat mata, sidik bibir ini disebut sidik bibir laten. Untuk membuktikan adanya sidik bibir tersebut maka harus digunakan beberapa alat bantu seperti bubuk aluminium atau bubuk magnetik supaya sidik bibir tersebut dapat terlihat dan nantinya dapat dianalisis polanya. Sedangkan sidik bibir yang tertinggal pada suatu benda dan dapat terlihat disebut sidik bibir tampak, sidik bibir ini sering tertinggal 
jika bibir orang yang memakai lipstik menyentuh benda lain. Hal ini disebabkan lipstik mengandung substansi kompleks yang mengandung beberapa komponen, seperti minyak dan malam (wax), sehingga dapat terlihat (Kaul et al., 2015).

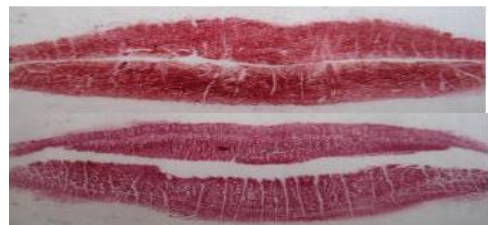

Gambar 2. Klasifikasi Sidik Bibir (Suzuki and Tsuchihashi 1971) Tipe I dan Ia (Randhawa et al., 2011).

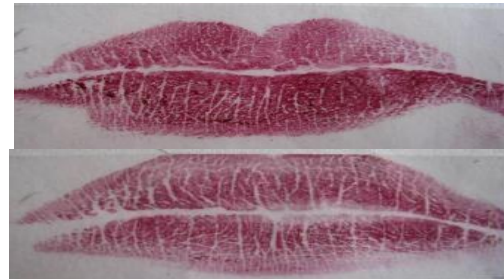

Gambar 3. Klasifikasi Sidik Bibir (Suzuki and Tsuchihashi 1971) Tipe II dan III (Randhawa et al., 2011).

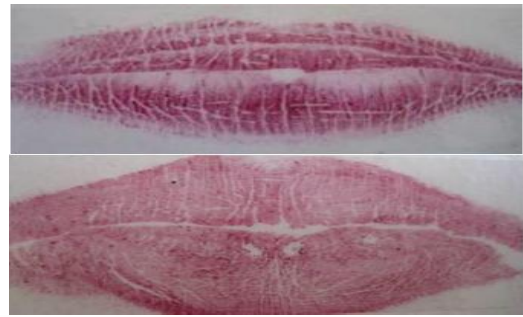

Gambar 4. Klasifikasi Sidik Bibir (Suzuki and Tsuchihashi 1971) Tipe IV dan V (Randhawa et al., 2011).

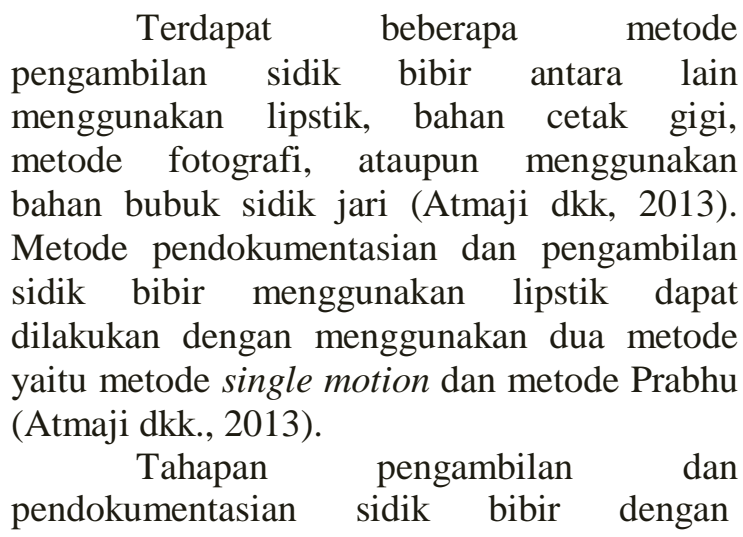

dioleskan pada bibir subyek secara merata, kemudian selotif ditempelkan pada bibir yang telah diolesi lipstik, lalu ditekan secara perlahan setelah itu selotif ditarik satu arah, dari kanan ke kiri atau kiri ke kanan. Perbedaan antara metode single motion dan metode prabu terletak pada cara penempelan selotif ke bibir subjek, jika pada metode single motion selotip ditempelkan searah dari arah kanan ke kiri atau sebaliknya kemudian selotif dilepas searah, akan tetapi jika metode prabu, selotif ditempelkan pada bibir bagian tengah kemudian baru selotif ditekankan pada bibir bagian kanan dan kiri (Reddy et al., 2011).

Pengambilan dan pendokumentasian sidik bibir dapat dilakukan dengan menggunakan bahan cetak kedokteran gigi seperti alginat, dan elastomer (polyvinyl siloxane). Munakhir (1995) melaporkan bahwa hasil cetakan sidik bibir dengan menggunakan alginat memberikan hasil yang cukup detail sehingga mudah dianalisa dan dapat bertahan lama. Dalam metode ini dibutuhkan alat dan bahan antara lain, mangkuk karet, spatula, alginat, dan sendok cetak perorangan (custom tray) (Atmaji dkk., 2013).

menggunakan metode lipstik yaitu, lipstik 
Jurnal Biosains Pascasarjana Vol. 17 (2015) pp

(C) (2015) Program Pascasarjana Universitas Airlangga, Indonesia

Sidik bibir dapat didokumentasikan

secara langsung dengan menggunakan foto

konvensional maupun foto digital.

Pemanfaatan foto digital lebih sering digunakan karena hasilnya dapat dilihat langsung sehingga pengambilan foto dapat diulang jika hasilnya kurang bagus. Selain itu hasil foto dapat dilakukan perbaikan kualitas gambar dengan menggunakan beberapa bantuan software seperti Adobe Photoshop (Atmaji dkk., 2013).

Sidik bibir dapat tertinggal pada sebuah benda seperti pada kain atau kemeja yang tidak dapat terlihat oleh mata. Dalam kasus ini sidik bibir dapat divisualisasikan dengan menggunakan bantuan bahan bubuk sidik jari serta bahan pewarna seperti lysochorme dye. Penggunaan bahan lysocrome dye akan sangat optimal jika diaplikasikan pada bahan yang memiliki porusitas, seperti kain, kertas tissue. Beberapa alat dan bahan yang dibutuhkan dalam metode ini adalah 
kuas, bubuk sidik jari atau bahan pewarna lysocrome dye (Atmaji dkk., 2013).

Sidik bibir dapat digunakan sebagai alat untuk identifikasi, sama seperti sidik jari dan gigi. Sidik bibir dapat terlihat di jendela, lukisan, pintu, kantong plastik, puntung rokok, dan dapat muncul berdampingan dengan jejak gigi pada makanan. Sidik bibir paling sering dapat terlihat pada kasus pembunuhan, perkosaan dan perampokan (Prabhu et al., 2012, Dineshshankar et al., 2013).

Penelitian Ball (2002) menunjukkan bukti konklusif bahwa sidik bibir cocok untuk perbandingan, analisis, dan identifikasi dari orang yang terlibat dalam kejahatan. Pelaku kejahatan dapat diidentifikasi secara positif melalui analisis sidik bibir melalui sidik bibir yang ditemukan di TKP (Rai et al., 2013). Sebuah sidik bibir di TKP bisa menjadi dasar kesimpulan mengenai karakter kejadian, jumlah orang yang terlibat, jenis kelamin, kosmetik yang digunakan, kebiasaan, sifat pekerjaan, dan perubahan patologis dari bibir itu sendiri untuk mempersempit penyelidikan (Prabhu et al., 2012, Vats et al., 2012, Rai et al., 2013).

Teknik cheiloscopy memiliki nilai yang sama dalam kaitannya dengan jenis lain dari bukti-bukti forensik untuk identifikasi personal dan penentuan jenis kelamin. Penelitian Kapoor et al., (2015) pada populasi Marathi di India Tengah ditemukan perbedaan yang signifikan antara pola sidik bibir pria dan wanita. Hal ini sama dengan penelitian Kautilya et al., (2013) di India Selatan dengan tipe III ditemukan paling dominan pada pria, sedangkan tipe I pada wanita. Penelitian Kaul et al., (2015) menunjukkan pola sidik bibir Tipe I adalah jenis yang paling dominan dari pola sidik bibir (pria 37,9\%, wanita 35,5\%). Hal ini serupa dengan hasil penelitian yang dilakukan oleh Randhawa et al., Vahanwala et al., dan Sandhu et al., (Kaul et al., 2015).

\subsubsection{Klasifikasi dan Metode Analisis Ruga Palatal}

Palatoscopy, atau rugoscopy palatal, adalah nama yang diberikan untuk studi tentang ruga palatal dalam rangka menentukan identitas seseorang, termasuk membantu penentuan jenis kelamin. Penggunaan ruga palatal pertama kali disarankan sebagai metode identifikasi pada tahun 1889 oleh Allen (Indira et al., 2012, Shetty et al., 2013).

Ruga palatal terdapat pada bagian anterior dari mukosa palatal di kedua sisi median raphe palatal dan belakang papilla insisivus tepat di belakang gigi insisivus sentral rahang atas. Daerah ini terdiri dari lipatan anatomis atau kerutan pada jaringan lunak palatal dan terdiri dari jaringan ikat fibrosa. Secara anatomis, ruga palatal terdiri dari sekitar 3-7 ridge kaku dan miring yang terbentang dari lateral membran papilla insisivus (Saraf et al., 2011, Senn et al., 2013, Azab et al., 2015). Ruga palatal telah terbukti sangat individualistis dan konsisten dalam bentuk sepanjang hidup. Pola ruga palatal unik untuk setiap individu termasuk kembar identik. Setelah terbentuk, ruga palatal tidak mengalami perubahan kecuali panjang, karena fase pertumbuhan palatal yang normal, dan tetap berada di posisi yang sama sepanjang hidup seseorang. Ruga palatal anterior tidak bertambah panjang setelah umur 10 tahun (Saraf et al., 2011).

Ruga palatal memiliki ketahanan yang cukup baik terhadap perubahan dari penyakit, trauma, dan zat kimia. Efek termal dan dekomposisi terhadap ruga palatal menunjukkan bahwa tidak banyak perubahan yang terjadi pada pola ruga palatal pada kasus kebakaran atau pada kadaver. Hasil penelitian menunjukkan bahwa 93\% dari korban kebakaran dengan luka bakar derajat tiga dan 77\% kadaver tidak terdapat perubahan pada pola ruga palatal. Meskipun jumlah sisanya mengalami perubahan, perubahan yang terjadi tidaklah sebesar perubahan yang terjadi pada bagian tubuh yang lain. Jadi ketika proses identifikasi dengan menggunakan analisa sidik jari tidak dapat dilakukan pada kasus kebakaran atau korban yang telah mengalami dekomposisi, analisa terhadap ruga palatal masih memungkinkan sehingga dapat membantu proses identifikasi (Indira et al., 2012, Azab et al., 2015). Adanya kebiasaan mengisap jempol yang ekstrim, pencabutan gigi, dan proses menua tidak cukup bisa 
merubah pola ruga palatal yang dapat mengganggu proses identifikasi (Senn et al., 2013). Tekanan akibat perawatan ortodonti dapat mengakibatkan perubahan morfometrik pada pola ruga palatal meliputi perubahan bentuk, panjang, unifikasi, dan terjadi anteroposterior displacement pada ujung ruga palatal bagian medial dan lateral (Mustafa et al., 2015).

Ruga palatal sangat baik karena posisinya yang terlindung dari trauma eksternal dan dari cedera termal oleh lidah dan jaringan lunak sekitarnya. Ruga palatal juga dapat mendukung bukti untuk identifikasi gigi forensik, terutama pada individu dengan rahang edentulous (Rotzsher et al., 2014). Keunikan, resistensi postmortem, stabilitas keseluruhan, dan biaya pemanfaatan yang rendah membuat ruga palatal menjadi salah satu parameter ideal dalam identifikasi forensik (Rai et al., 2013).

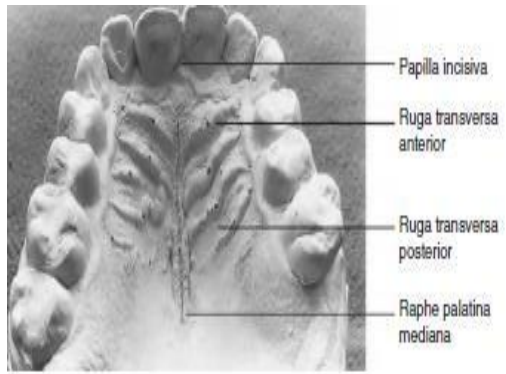

Gambar 5. Ruga palatal pada model studi (Rotzsher et al., 2014)

Sistem klasifikasi pertama dikembangkan oleh Goria pada tahun 1911 dan belum sempurna. Pola ruga palatal dikategorikan dalam dua cara yaitu menentukan jumlah ruga palatal dan menentukan sejauh mana zona relatif ruga palatal pada gigi. Dalam sistem ini, gabungan ruga palatal dari dua atau lebih percabangan dihitung sebagai satu, apakah berbentuk V atau Y. Klasifikasi Lysell pada tahun 1955 adalah yang paling penting, dan telah digunakan secara luas dalam penelitian yang melibatkan ruga palatal. Hal ini komprehensif dan mencakup inter ruga palatal (IR). Ruga palatal diukur dan diklasifikasikan menjadi tiga kategori yaitu ruga palatal primer $(\geq 5$ $\mathrm{mm})$, ruga palatal sekunder $(3-5 \mathrm{~mm})$, dan fragmentary ruga palatal (2-3 $\mathrm{mm}$ ) (Rai et al., 2013). Ruga palatal dengan panjang lebih kecil dari 2 mm diabaikan karena membentuk gambar yang agak sederhana dari bentuk rumit ruga palatal yang biasanya. Oleh karena itu, Thomas dan Kotze (1983) mengklasifikasikan berbagai pola ruga palatal primer menjadi lebih rinci (Rai et al., 2013).

Klasifikasi Thomas dan Kotze adalah klasifikasi yang cukup sering dipakai karena praktis dan mudah diterapkan. Klasifikasi tersebut meliputi panjang, bentuk, dan unifikasi dari ruga palatal. Panjang ruga palatal dibagi atas ruga palatal primer $(>5$ $\mathrm{mm})$, ruga palatal sekunder (3-5 $\mathrm{mm})$. Bentuk ruga palatal diklasifikasikan menjadi kurva (curved), bergelombang (wavy), lurus (straight) dan sirkular (circular). Unifikasi dibagi menjadi konvergen dimana dua ruga palatal berasal jauh dari bagian tengah atau pusat dan menyatu saat menuju bagian tengah, dan divergen dimana ruga palatal berasal dari pusat dan menyebar saat menjauh dari pusat (Barath et al., 2011, Saraf et al., 2011).

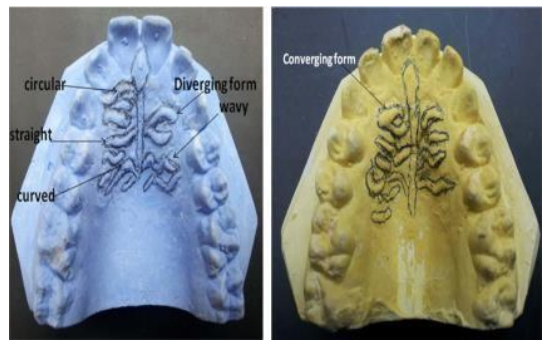

Gambar 6. Macam bentuk pola ruga palatal pada model studi (Azab et al.,2015)

Klasifikasi tambahan dari Martins dos Santos, yang didasarkan pada bentuk dan posisi masing-masing ruga palatal. Klasifikasi ini menunjukkan karakteristik sebagai berikut (Indira et al., 2012) :

1. Satu initial ruga palatal : Satu ruga palatal yang paling anterior di sisi kanan dilambangkan dengan huruf kapital.

2. Beberapa ruga palatal tambahan : Ruga palatal lainnya di sisi kanan yang dilambangkan dengan angka. 
3. Satu subinitial ruga palatal : Satu ruga palatal yang paling anterior di sisi kiri dilambangkan dengan huruf kapital.

4. Beberapa subcomplementary ruga palatal : Ruga palatal lainnya di sisi kiri yang dilambangkan dengan angka. Klasifikasi Basauri adalah klasifikasi yang sangat mudah digunakan. Klasifikasi ini membedakan antara initial ruga palatal atau ruga palatal utama, yang merupakan ruga palatal paling anterior (diberi lambang huruf), dan ruga palatal tambahan, yang merupakan semua ruga palatal yang tersisa (diberi lambang nomor) (Rai et al., 2013).

Tabel 1. Klasifikasi Matins dos Santos (Mishra et al., 2015)

\begin{tabular}{|l|c|c|}
\hline Tipe Ruga & $\begin{array}{l}\text { Posisi } \\
\text { Anterior }\end{array}$ & $\begin{array}{l}\text { Posisi } \\
\text { Lain }\end{array}$ \\
\hline Titik (Point) & P & 0 \\
\hline Garis (Line) & L & 1 \\
\hline Kurva (Curve) & C & 2 \\
\hline Bersudut (Angle) & A & 3 \\
\hline Sirkular (Circle) & C & 4 \\
\hline $\begin{array}{l}\text { Bergelombang } \\
\text { (Sinuous) }\end{array}$ & S & 5 \\
\hline Bifurkasi & B & 6 \\
\hline Trifurkasi & T & 7 \\
\hline Interrupt & I & 8 \\
\hline Anomaly & An & 9 \\
\hline
\end{tabular}

Tabel 2. Klasifikasi Basauri (Mishra et al., 2015)

\begin{tabular}{|c|c|l|}
\hline $\begin{array}{c}\text { Klasifikasi } \\
\text { Ruga } \\
\text { Utama }\end{array}$ & $\begin{array}{c}\text { Klasifikasi } \\
\text { Ruga } \\
\text { Tambahan }\end{array}$ & Anatomi Ruga \\
\hline A & 1 & Titik (Point) \\
\hline B & 2 & Garis (Line) \\
\hline C & 3 & $\begin{array}{l}\text { Bersudut } \\
(\text { Angle })\end{array}$ \\
\hline D & 4 & $\begin{array}{l}\text { Bergelombang } \\
(\text { Sinuous })\end{array}$ \\
\hline E & 5 & Kurva $($ Curve $)$ \\
\hline F & 6 & $\begin{array}{l}\text { Sirkular } \\
(\text { Circle })\end{array}$ \\
\hline X & 7 & Polimorfik \\
\hline
\end{tabular}

Terdapat beberapa cara dalam menganalisis ruga palatal antara lain pemeriksaan intra oral, membuat fotografi oral, pembuatan cetakan, dan stereophotogrammetry. Pemeriksaan intraoral merupakan cara yang paling mudah, murah, dimana cukup dengan menggunakan kaca mulut dapat dilihat gambaran ruga palatal dari seseorang. Namun cara ini sulit digunakan bila hendak membandingkan antara ruga palatal satu individu dengan individu yang lain. Membuat fotografi oral dengan menggunakan kamera intra oral. Cara ini memungkinkan perbandingan ruga palatal antar individu. Stereophotogrammetry yaitu dengan menggunakan perangkat khusus yang disebut Traster Marker dapat dilakukan penentuan dengan tepat panjang dan posisi setiap ruga palatal.

Cara pembuatan cetakan merupakan cara yang mudah dan murah yaitu cukup dengan mencetak rahang atas individu. Rahang dicetak dengan menggunakan irreversible hydrocolloid dan diisi dengan dental stone. Hasil cetakan harus bebas dari porus atau gelembung udara terutama pada bagian anterior dari palatum. Dengan bantuan kaca pembesar, ruga palatal pada model gigi diwarnai dengan pensil atau bolpoin hitam untuk memperjelas gambaran pola dari ruga palatal. Bila perlu, dapat dibuat foto dan dianalisa dengan program Photoshop. Pengukuran ruga palatal dapat menggunakan kaliper atau penggaris (contohnya penggaris Kenson). Karena kesederhanaannya, harga, dan kehandalan studi cetakan gigi rahang atas adalah teknik yang paling umum.

Ruga palatal yang menonjol, permanen, dan unik bagi individu dapat digunakan sebagai identifikasi untuk tujuan forensik. Hal ini banyak digunakan pada pasien edentulous dimana identifikasi gigi tidak mungkin dilakukan dan pada pasien dimana bagian tubuh lainnya terbakar atau mengalami pembusukan (Byatnal et al., 2014).

Sebuah hubungan yang signifikan terlihat antara bentuk ruga palatal dan etnis. Kapali dan rekannya mempelajari pola ruga palatal antara populasi aborigin Australian dan Caucasians. Mereka mengamati jumlah, panjang, bentuk, arah, dan penyatuan ruga palatal. Penelitian tersebut menunjukkan 
bahwa jumlah rata-rata ruga palatal utama pada aborigin Australian lebih tinggi daripada Caucasians, namun untuk ruga palatal utama dengan panjang lebih dari $10 \mathrm{~mm}$ jumlahnya pada Caucasians lebih banyak dari aborigin Australian. Bentuk lurus dari ruga palatal lebih banyak ditemukan pada Caucasians sedangkan bentuk bergelombang lebih banyak pada aborigin Australian (Rai et al., 2013).

Pola morfologi ruga palatal mungkin berguna dalam ilmu forensik dalam kasus mutilasi bila dibandingkan dengan bagian lain dari tubuh. Ruga palatal membentuk pola intrinsik dan integral untuk setiap individu dan juga dapat membantu dalam penentuan jenis kelamin (Shetty et al., 2013). Penelitian Barath et al., (2011) dari populasi Andhra di pesisir India mengungkapkan perbedaan unifikasi ruga palatal antara pria dan wanita yang ditemukan signifikan secara statistik, tetapi tidak untuk jumlah ruga palatal. Perbedaan signifikan juga ditemukan antara pria dan wanita yang terlihat pada pola ruga palatal baik bentuk dan jumlah dalam penelitian oleh Saraf et al., (2011) di India dan Fahmi et al., (2001) di Mesir. Shetty et al., (2013) mempelajari dan membandingkan pola ruga palatal antara pria dan wanita pada populasi di India bagian barat. Jumlah rata-rata ruga palatal pada wanita sedikit lebih tinggi dibandingkan pada pria, dan pola divergen ruga palatal ditemukan lebih dominan pada wanita dibandingkan pada pria.

Pada individu tidak bergigi (edentulous) terjadi pengurangan jumlah ruga palatal, panjang ruga palatal yang memendek, dan posisi ruga palatal yang dominan adalah ruga palatal yang lebih anterior dan lateral dibandingkan dengan individu muda yang masih bergigi (Rai et al., 2013).

\section{METODE PENELITIAN}

Jenis penelitian yang digunakan adalah penelitian observasional analitik. Desain dari penelitian ini adalah penelitian cross sectional untuk melihat perbedaan reliabilitas antara pola sidik bibir dan pola ruga palatal dalam penentuan jenis kelamin. 
Jurnal Biosains Pascasarjana Vol. 17 (2015) pp

(C) (2015) Program Pascasarjana Universitas Airlangga, Indonesia

Penelitian ini menggunakan 68 sampel

(34 pria dan 34 wanita) mahasiswa Kedokteran

Gigi Universitas Airlangga Surabaya kisaran usia 21-30 tahun yang memenuhi kriteria penelitian.

Teknik yang digunakan untuk pemilihan sampel adalah teknik simple random sampling. Kriteria sampel penelitian meliputi :

1. Memiliki kondisi bibir yang sehat (tidak mengalami inflamasi, tidak terdapat lesi pada bibir, abnormalitas atau deformitas seperti cleft lip, bekas luka post operasi).

2. Memiliki kondisi palatum yang sehat (tidak mengalami kelainan kongenital atau malformasi, tidak memiliki riwayat operasi orthognatic, tidak terdapat lesi pada palatum, trauma, penonjolan tulang dan jaringan lunak).

3. Tidak sedang atau telah menjalani perawatan ortodonti.

4. Tidak memiliki riwayat alergi atau atau reaksi hipersensitivitas terhadap lipstik dan bahan-bahan cetak Kedokteran Gigi.

Prosedur penelitian meliputi :

1. Responden yang akan diteliti harus sesuai dengan kriteria yang telah ditentukan dan selanjutnya menyatakan kesediaannya dengan mengisi inform consent dan kuisioner yang telah disediakan oleh peneliti.

2. Responden diminta duduk tegak dan rileks. Bibir atas dan bawah dibersihkan dengan kapas yang telah dibasahi dengan air untuk menghilangkan kotoran pada bibir. Pada responden yang sudah menggunakan lipstik sebelumnya, dibersihkan dengan kapas yang telah dibasahi dengan lipstick remover. Bibir atas dan bawah kemudian dikeringkan dengan tissue.

3. Lipstik diulas dengan menggunakan kuas hingga merata ke seluruh bagian bibir atas dan bawah. Ditunggu 1-2 menit.

4. Selotip transparan yang telah disiapkan dilekatkan pada bibir dengan posisi bibir istirahat normal, 
ditempelkan dan ditekan searah dari arah kanan ke kiri (metode single motion). Ditahan beberapa detik.

5. Selotip dilepaskan searah dari bibir secara perlahan kemudian ditempel pada kertas HVS A4 80 gsm dan ditulis identitas.

6. Responden didudukkan dengan posisi kepala, tubuh berada dalam satu garis lurus, tegak, dan rileks. Responden disuruh agar bernafas melalui hidung.

7. Memilih sendok cetak yang tepat, sesuai dengan besar rahang atas responden.

8. Menyiapkan alginat secukupnya ke dalam bowl dan diberi air secukupnya kemudian diaduk dengan spatula sampai tercampur rata, kemudian segera diletakkan pada sendok cetak yang sudah dipilih.

9. Tinggi kursi diatur sedemikian rupa sehingga mulut pasien setinggi siku operator. Operator di belakang kanan. Sendok cetak dipegang dengan tangan kanan dan tangan kiri membuka ujung mulut sebelah kiri.

10. Sendok cetak dimasukkan ke dalam mulut responden secara berputar pada sudut mulut kanan sampai gagang sendok cetak terletak pada satu garis dengan hidung responden.

11. Bagian posterior sendok cetak ditekan terlebih dahulu. Kepala responden ditundukkan.

12. Sendok cetak ditahan dengan tekanan yang konstan dan ditunggu selama 2-3 menit sampai bahan cetak mengeras.

13. Setelah bahan cetak keras, sendok cetak beserta hasil cetakan dikeluarkan dari mulut secara perlahan.

14. Hasil cetakan diisi dengan gips / dental stone tipe III dengan cara gips dicampur dengan air dan diaduk sampai homogen kemudian dituangkan pada bagian yang paling tinggi (daerah palatum), sambil mengetok-ngetokkan sendok cetak diatas rubber bowl untuk mencegah terjadinya gelembung udara yang menyebabkan porus.

15. Setelah gips mengeras, cetakan yang berupa model dapat dikeluarkan secara perlahan dan ditulis identitas.

16. Hasil sidik bibir dibagi menjadi 6 bagian atau kuadran yaitu Upper Right (UR), Upper Middle (UM), Upper Left (UL), Lower Left (LL), Lower Middle (LM) dan Lower Right (LR).

17. Masing-masing bagian atau kuadran diamati pola sidik bibirnya dengan menggunakan kaca pembesar.

Perbandingan tipe pola sidik bibir sesuai klasifikasi Suzuki dan Tshuchihashi. Perbandingan bentuk pola ruga palatal sesuai klasifikasi Thomas dan Kotze.Kedua hasil sidik bibir dan ruga palatal tersebut diamati oleh dua orang pengamat dan dianalisa. Hasil analisa jika antara kedua pengamat tersebut konsisten, maka 38 sampel berikutnya dilakukan oleh satu pengamat.

Analisis data menggunakan Koefisien Cohen's Kappa untuk menilai tingkat kesepakatan (degree of agreement) dari dua pengamat serta menilai reliabilitas pola sidik bibir dan pola ruga palatal dalam penentuan jenis kelamin. Uji chi-square untuk melihat apakah terdapat hubungan pola sidik bibir dan ruga palatal dengan jenis kelamin.

\section{HASIL DAN PEMBAHASAN}

Tabel 3. Reliabilitas pola sidik bibir dan pola ruga palatal

\begin{tabular}{|l|c|l|}
\hline & $\begin{array}{c}\text { Kappa } \\
(\mathrm{K})\end{array}$ & $\begin{array}{l}\text { Signifikans } \\
\mathrm{i}\end{array}$ \\
\hline $\begin{array}{l}\text { Reliabilitas pola } \\
\text { sidik bibir }\end{array}$ & 0,834 & 0,000 \\
\hline $\begin{array}{l}\text { Reliabilitas pola ruga } \\
\text { palatal }\end{array}$ & 0,593 & 0,000 \\
\hline
\end{tabular}

Tabel 3 menunjukkan reliabilitas pola sidik bibir kategori sangat baik. Sedangkan reliabilitas pola ruga palatal dengan kategori sedang. Keduanya didapatkan nilai signifikansi sebesar 0,000. Hal ini menunjukkan nilai koefisien antar pengamat 
saling berkorelasi dan antara kedua pengamat konsisten.

Hasil uji reliabilitas pola sidik bibir dan pola ruga palatal yang dianalisis dengan menggunakan analisis inter-rater reliability (IRR) koefisien Cohen's Kappa terhadap kesepakatan (agreement) dua orang penilai atau pengamat menunjukkan bahwa reliabilitas pola sidik bibir lebih tinggi daripada reliabilitas pola ruga palatal dalam penentuan jenis kelamin. Perbedaan reliabilitas tersebut sesuai dengan kesepakatan dua pengamat dengan kategori 'sangat baik' pada pola sidik bibir, sedangkan kategori 'sedang' terhadap kesepakatan dua pengamat pada pola ruga palatal. Hasil penelitian oleh Nagalaxmi et al. (2014) juga menunjukkan bahwa pola sidik bibir memberikan prediksi jenis kelamin lebih handal dari pola ruga palatal.

Hasil kesepakatan yang sangat baik diantara dua pengamat pada pola sidik bibir mungkin karena faktor usia sampel yang digunakan pada penelitian. Penelitian yang dilakukan oleh Kapoor et al. (2015) dengan sampel usia 18-25 tahun juga menunjukkan bahwa kesepakatan pola sidik bibir antara kedua pengamat 'sangat baik'. Demikian halnya dengan Nagalaxmi et al. (2014) dengan sampel usia 20-30 tahun menunjukkan kesepakatan kedua pengamat 'baik'. Hasil yang berbeda ditunjukkan oleh Kaul et al. (2015) yang mengambil 755 sampel dengan usia 1 tahun hingga 41 tahun ke atas menunjukkan nilai Kappa (K) yang rendah. Perbedaan hasil tersebut menunjukkan bahwa faktor usia mempengaruhi sidik bibir.

Bibir mencapai kematangan pada akhir masa remaja. Wanita mencapai kematangan bibir atas pada 14 tahun dan bibir bawah pada 16 tahun, sedangkan pada pria, baik atas serta bibir bawah pada 18 tahun. Pada pertengahan ke akhir 30-an, meskipun perubahan usia mulai terjadi di wajah bagian atas, bibir mempertahankan tonisitas dan tidak menunjukkan perubahan. Setelah 40 tahun, karena keriput pada kulit dan penipisan bibir yang berdekatan, pola sidik bibir juga terpengaruh. Volume bibir dan daerah perioral menjadi berkurang dan mengurangi anatomi bibir secara keseluruhan (Gordon, 2010).
Sidik bibir diambil dalam posisi bibir tertutup atau istirahat normal dan santai. Faktor tersebut mungkin juga mempengaruhi kesepakatan dua pengamat. Keunikan pola sidik bibir tergantung pada cara otot bibir yang santai untuk menghasilkan pola tertentu. Juga, alur bibir dengan mulut tertutup dapat terdefinisikan dengan baik, sedangkan di posisi mulut terbuka alur tidak terdefinisikan dengan baik dan oleh karena itu sulit untuk menafsirkan (Gondivkar et al., 2009).

Hasil kesepakatan diantara dua pengamat dengan kategori 'sedang' pada pola ruga palatal mungkin disebabkan karena faktor subjektivitas diantara kedua pengamat. Para peneliti sebelumnya telah menemukan kesulitan dalam klasifikasi pola ruga palatal karena sifat subjektif pada saat observasi dan interpretasi diantara pengamat (Barath et al., 2011). Selain itu, mungkin juga disebabkan karena adanya porus atau gelembung udara akibat proses pencetakan rahang atas yang kurang baik ataupun pada proses pengisian gips sehingga bentuk ruga palatal kurang tercetak dengan sempurna.

Kesalahan tersebut mungkin dapat dikurangi dengan pengembangan perangkat pemindaian intraoral untuk menangkap pola ruga palatal dengan transfer gambar secara langsung ke komputer dengan software yang tepat, seperti sidik jari. Hal ini akan mengurangi kesalahan pengamat dalam proses kategorisasi sampel pola ruga palatal. (Saraf et al., 2011). 
Jurnal Biosains Pascasarjana Vol. 17 (2015) pp

(C) (2015) Program Pascasarjana Universitas Airlangga, Indonesia

Tabel 4. Distribusi pola sidik bibir pada semua kuadran bibir

\begin{tabular}{|l|l|l|l|l|}
\hline \multirow{2}{*}{$\begin{array}{l}\text { Pola Sidik } \\
\text { Bibir }\end{array}$} & \multirow{2}{*}{ Pria } & \multicolumn{2}{l|}{$\begin{array}{l}\text { Wanit } \\
\text { a }\end{array}$} \\
\cline { 2 - 5 } & $\mathrm{n}$ & $\%$ & $\mathrm{n}$ & $\%$ \\
\hline Tipe I & 4 & $\begin{array}{l}11,7 \\
7\end{array}$ & 5 & $\begin{array}{l}14,7 \\
1\end{array}$ \\
\hline Tipe Ia & 5 & $\begin{array}{l}14,7 \\
0\end{array}$ & 14 & $\begin{array}{l}41,1 \\
8\end{array}$ \\
\hline Tipe II & 2 & 5,88 & 8 & $\begin{array}{l}23,5 \\
3\end{array}$ \\
\hline Tipe III & 13 & $\begin{array}{l}38,2 \\
4\end{array}$ & 6 & $\begin{array}{l}17,6 \\
5\end{array}$ \\
\hline Tipe IV & 3 & 8,82 & 1 & 2,94 \\
\hline Tipe V & 7 & $\begin{array}{l}20,5 \\
9\end{array}$ & 0 & 0 \\
\hline Total & 34 & 100 & 34 & 100 \\
\hline
\end{tabular}

Tabel 5. Distribusi pola sidik bibir pada setiap kuadran bibir

\begin{tabular}{|l|l|l|l|l|l|l|l|}
\hline \multirow{2}{*}{} & \multirow{2}{*}{\begin{tabular}{l} 
Kenis \\
\cline { 3 - 8 }
\end{tabular}} & & \multicolumn{9}{|c|}{$\begin{array}{l}\text { pr } \\
\text { Kelamin }\end{array}$} & $\begin{array}{l}\text { Tipe } \\
\text { I }\end{array}$ & $\begin{array}{l}\text { Tipe } \\
\text { Ia }\end{array}$ & $\begin{array}{l}\text { Tipe } \\
\text { II }\end{array}$ & $\begin{array}{l}\text { Tipe } \\
\text { III }\end{array}$ & $\begin{array}{l}\text { Tipe } \\
\text { IV }\end{array}$ & $\begin{array}{l}\text { Tipe } \\
\text { V }\end{array}$ \\
\hline UR & Pria & 9 & 7 & 3 & 10 & 4 & 3 \\
\hline & Wanita & 5 & 12 & 8 & 7 & 2 & 0 \\
\hline UM & Pria & 4 & 4 & 3 & 4 & 8 & 9 \\
\hline & Wanita & 3 & 18 & 6 & 2 & 4 & 1 \\
\hline UL & Pria & 4 & 8 & 8 & 11 & 2 & 1 \\
\hline & Wanita & 5 & 9 & 10 & 9 & 1 & 0 \\
\hline LR & Pria & 2 & 12 & 2 & 13 & 1 & 4 \\
\hline & Wanita & 8 & 8 & 6 & 12 & 0 & 0 \\
\hline LM & Pria & 3 & 12 & 2 & 5 & 5 & 7 \\
\hline & Wanita & 11 & 16 & 4 & 3 & 0 & 0 \\
\hline LL & Pria & 3 & 5 & 3 & 15 & 3 & 5 \\
\hline & Wanita & 6 & 8 & 10 & 9 & 1 & 0 \\
\hline
\end{tabular}

Pada penelitian ini ditemukan bahwa tidak ada dua individu atau lebih dari dua individu memiliki pola sidik bibir yang identik sesuai dengan penelitian lain yang dilakukan oleh Tsuchihashi pada tahun 1974 terhadap 1364 subyek Jepang (757 laki-laki dan 607 perempuan) (Vahanwala et al., 2005) dan juga seperti penelitian lain yang dilakukan oleh
Rohit et al. (2011), Patel et al. (2010), dan Gondivkar et al. (2009).

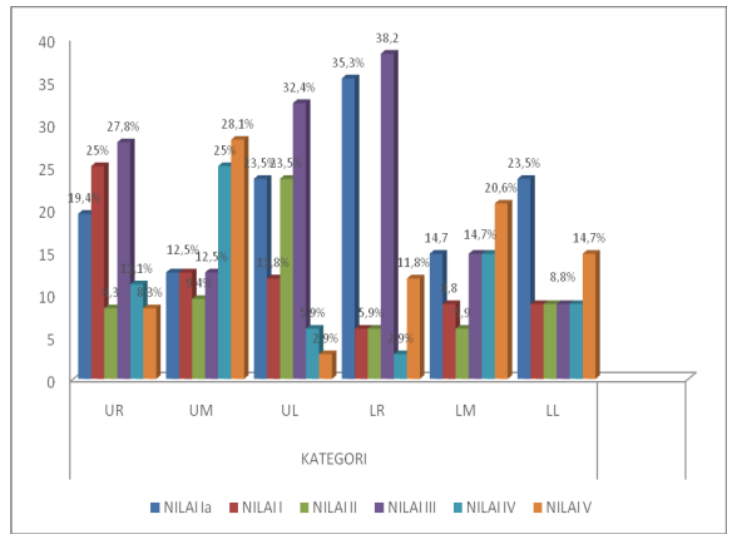

Gambar 7. Diagram batang proporsi tipe pola sidik bibir pada setiap kuadran pada pria

Berdasarkan Tabel 5 dapat diketahui pr porsi tipe pola sidik bibir pada setiap kuadran bibir dalam diagram batang yang
tel lihat pada gambar 7 dan 8 . Berdasarkan mbar 7 diketahui bahwa:

1. Tipe III mendominasi kuadran UR dengan proporsi sebesar 27,8\%. Sedangkan proporsi terendah dimiliki oleh tipe II dan $\mathrm{V}$ dengan proporsi yang sama yaitu sebesar $8,3 \%$

2. Tipe $\mathrm{V}$ merupakan tipe yang mendominasi kuadran UM dengan proposi sebesar 28,1\% ,sedangkan proposi terendah dimiliki oleh tipe II dengan proporsi $9,4 \%$.

3. Tipe III merupakan tipe yang mendominasi kuadran UL dengan proporsi $32,4 \%$, sedangkan proporsi terendah dimiliki oleh tipe $\mathrm{V}$ dengan proporsi $2,9 \%$.

4. Tipe III merupakan tipe yang mendominasi kuadran LR dengan proporsi $38,2 \%$, sedangkan proporsi terendah dimiliki oleh tipe IV dengan $2,9 \%$.

5. Tipe $\mathrm{V}$ merupakan tipe yang mendominasi kuadran LM dengan proporsi $20,6 \%$, sedangkan proporsi 
terendah dimiliki oleh tipe II dengan proporsi $5,9 \%$.

6. Tipe Ia merupakan tipe yang mendominasi kuadran LL dengan proporsi $23,5 \%$, sedangkan proporsi terendah dimiliki oleh tipe Ia,I,II,III,dan IV dengan proporsi yang sama yaitu sebesar $8,8 \%$.

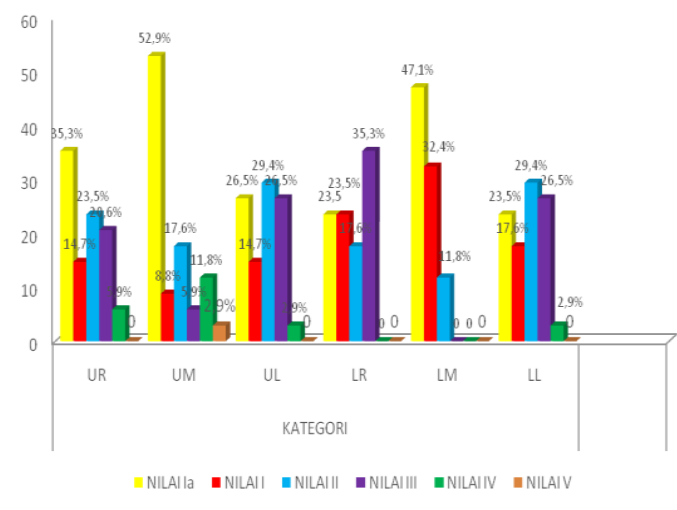

Gambar 8. Diagram batang proporsi tipe pola sidik bibir pada setiap kuadran pada wanita

bahwa:

Berdasarkan gambar 8 diketahui

1. Tipe Ia mendominasi kuadran UR dengan proporsi sebesar 35,5\%. Sedangkan sisanya yaitu tipe I,II,III,IV, dan V masing-masing memiliki proporsi sebesar $14,7 \%$, $23,5 \%, 20,6 \%, 5,9 \%$, dan $0 \%$.

2. Tipe Ia merupakan tipe yang mendominasi kuadran UM dengan proposi sebesar 52,9\%, sedangkan proposi terendah dimiliki oleh tipe $\mathrm{V}$ dengan proporsi $2,9 \%$.

3. Tipe II merupakan tipe yang mendominasi kuadran UL dengan proporsi $29,4 \%$, sedangkan proporsi terendah dimiliki oleh tipe $\mathrm{V}$ dengan proporsi $0 \%$.

4. Tipe III merupakan tipe yang mendominasi kuadran LR dengan proporsi 35,3\%, sedangkan proporsi terendah dimiliki oleh tipe IV dan V dengan proporsi yang sama yaitu $0 \%$.
5. Tipe Ia merupakan tipe yang mendominasi kuadran LM dengan proporsi $47,1 \%$, sedangkan proporsi terendah dimiliki oleh tipe III,IV dan $\mathrm{V}$ dengan proporsi yang sama yaitu sebesar $0 \%$.

6. Tipe II merupakan tipe yang mendominasi kuadran LL dengan proporsi $29,4 \%$, sedangkan proporsi terendah dimiliki oleh tipe $\mathrm{V}$ dengan proporsi $0 \%$.

Hasil analisis Chi-Square Test terhadap pola sidik bibir pada semua kuadran bibir (yang dominan terlihat dari keenam kuadran bibir) terlihat pada tabel 8 dapat disimpulkan bahwa terdapat hubungan antara pola sidik bibir dengan jenis kelamin. Hasil penelitian ini sesuai dengan penelitian Kapoor et al. (2015) pada populasi Marathi di India Tengah dan penelitian Kautilya et al. (2013) pada populasi India Selatan yang menemukan perbedaan yang signifikan antara pola sidik bibir pria dan wanita dengan pola tipe I ditemukan banyak pada wanita dan tipe III pada pria. Namun berbeda dengan penelitian Augustine et al. (2008) pada populasi di India yang tidak menemukan perbedaan signifikan dalam pola sidik bibir berdasarkan jenis kelamin. Hal ini disebabkan karena perbedaan usia sampel penelitian.

Penelitian Kapoor et al. (2015) mengambil sampel dengan kisaran usia 18-25 tahun. Demikian juga dengan Kautilya et al. (2013) yang mengambil mahasiswa kedokteran sebagai sampel, sedangkan penelitian Augustine et al. (2008) mengambil sampel dengan kisaran usia 3-83 tahun. Hal ini menunjukkan bahwa faktor usia mempengaruhi sidik bibir. 
Tabel 6. Hasil analisa Chi-Square Test pola sidik bibir tiap kuadran bibir

\begin{tabular}{|l|c|c|c|c|c|c|}
\hline & $(\mathrm{U}$ & & & $(\mathrm{L}$ & & \\
& $\mathrm{R})$ & $(\mathrm{U}$ & $(\mathrm{U}$ & $\mathrm{R})$ & $(\mathrm{L}$ & $(\mathrm{LL})$ \\
$\mathrm{M})$ & $\mathrm{L})$ & & $\mathrm{M})$ & \\
\hline $\mathrm{x}^{2}$ & 9,7 & 19, & 1,9 & 11, & 17, & 12,9 \\
& 88 & 661 & 25 & 440 & 410 & 62 \\
\hline $\mathrm{df}$ & 5 & 5 & 5 & 5 & 5 & 5 \\
\hline $\mathrm{p}$ & 0,0 & 0,0 & 0,8 & 0,0 & 0,0 & 0,02 \\
& 81 & 01 & 59 & 43 & 04 & 4 \\
\hline
\end{tabular}

Keterangan : $\mathrm{x}^{2}=$ Value of Chi-Square, $\mathrm{df}=$ Degree of freedom

Pada sebuah kasus tidak jarang ditemukan sidik bibir sebagian di TKP, oleh karena itu, pola sidik bibir harus diamati secara terpisah. Bibir masing-masing individu dibagi menjadi enam bagian, tiga bagian di bibir atas (atas kanan / UR, atas tengah / UM, atas kiri / UL) dan tiga di bibir bawah (bawah kanan / LR, bawah tengah / LM, bawah kiri / LL) mengikuti metode yang dilakukan Kautilya et al (2013).

Pada bibir bawah bagian kanan (LR) baik pada pria maupun wanita banyak ditemukan pola sidik bibir tipe III (menyilang). Penelitian Augustine et al. (2008) juga menemukan pada bibir bawah bagian lateral (kanan dan kiri) banyak terlihat pola sidik bibir tipe III. Hal ini mungkin disebabkan karena hasil kontinuitas garis-garis pada kulit yang berdekatan dengan bibir pada daerah tersebut, sehingga terlihat memotong atau menyilang (Leveque et al., 2004).

Penelitian ini menunjukkan bahwa tidak terlihat jenis tipe pola yang sama pada keenam kuadran sidik bibir pada wanita dan laki-laki. Dari keseluruhan sampel terlihat dua sampai tiga jenis tipe pola pada keenam kuadran sidik bibir. Keunikan pola sidik bibir tergantung dari cara otot bibir yang santai untuk menghasilkan pola tertentu (Sivapathasundharam et al., 2001). Alur dan garis bibir merupakan daerah utama penyebaran saliva pada seluruh bibir untuk mempertahankan hidrasi yang baik. Bibir atas lebih terhidrasi dengan baik daripada bibir bawah. Faktor tersebut mungkin mempengaruhi bervariasinya pola pada bibir atas dan bawah (Leveque et al., 2004). 
Jurnal Biosains Pascasarjana Vol. 17 (2015) pp

(C) (2015) Program Pascasarjana Universitas Airlangga, Indonesia

Hasil uji Chi-Square terhadap pola sidik bibir pada tiap kuadran pembagian bibir terlihat pada tabel 6 disimpulkan bahwa terdapat hubungan antara pola sidik bibir dengan jenis kelamin pada bibir atas bagian tengah dan ketiga bagian bibir bawah, namun, tidak terdapat hubungan antara pola sidik bibir pada bibir atas bagian kanan dan kiri dengan jenis kelamin.

Garis dan alur yang tampak pada bibir atas dan bawah dari satu sudut mulut ke sudut yang lain, tetapi hanya bagian tengah bibir yang diperhitungkan, karena bagian tersebut yang selalu terlihat jika terdapat sidik bibir pada jejak (Dongarwar et al., 2013, Kaul et al., 2015). Pada keenam kuadran sidik bibir, secara statistik sangat signifikan ditunjukkan pada bibir atas bagian tengah (UM) ( $\mathrm{p}=$ 0,001 ) diikuti oleh bibir bawah bagian tengah $(\mathrm{LM})(\mathrm{p}=0,004)$. Hal tersebut menunjukkan pada bagian tengah bibir atas maupun bawah mungkin dapat secara efektif dan efisien digunakan untuk penentuan jenis kelamin.

Tabel 7.

\begin{tabular}{|l|l|l|l|l|}
\hline \multirow{2}{*}{$\begin{array}{l}\text { Pola Ruga } \\
\text { Palatal }\end{array}$} & \multicolumn{1}{l}{$\begin{array}{l}\text { Pri } \\
\mathrm{a}\end{array}$} & \multicolumn{2}{l|}{$\begin{array}{l}\text { Wani } \\
\text { ta }\end{array}$} \\
\cline { 2 - 5 } & $\mathrm{N}$ & $\%$ & $\mathrm{n}$ & $\%$ \\
\hline Lurus (straight) & 21 & $\begin{array}{l}61, \\
8\end{array}$ & 18 & $\begin{array}{l}52, \\
9\end{array}$ \\
\hline $\begin{array}{l}\text { Bergelombang } \\
\text { (wavy) }\end{array}$ & 12 & $\begin{array}{l}35, \\
3\end{array}$ & 15 & $\begin{array}{l}44, \\
1\end{array}$ \\
\hline Kurva (curve) & 0 & 0 & 1 & 2,9 \\
\hline $\begin{array}{l}\text { Sirkular } \\
\text { (circular) }\end{array}$ & 1 & 2,9 & 0 & 0 \\
\hline Total & 34 & 100 & 34 & 100 \\
\hline
\end{tabular}

Tabel 8. Hasil analisa Chi-Square Test pola sidik bibir dan pola ruga palatal

Keterangan $: x^{2}=$ Value of Chi-Square, $\mathrm{df}=$

\begin{tabular}{|l|l|l|}
\hline & Pola Sidik Bibir & $\begin{array}{l}\text { Pola Ruga } \\
\text { Palatal }\end{array}$ \\
\hline $\mathrm{x}^{2}$ & 18,553 & 2,564 \\
\hline df & 5 & 3 \\
\hline $\mathrm{p}$ & 0,002 & 0,464 \\
\hline
\end{tabular}

Degree of freedom

Pada penelitian ini ditemukan bahwa masing-masing sampel memiliki pola ruga palatal yang berbeda. Namun dalam perbedaan 
kedua jenis kelamin, tidak ditemukan perbedaan yang signifikan. Ruga palatal bentuk lurus ditemukan lebih dominan baik pada pria maupun wanita, terlihat pada tabel 7 . Bisa disimpulkan bahwa pola ruga palatal menunjukkan pola yang khas namun tidak ada pola karakteristik tertentu yang terlihat pada kedua jenis kelamin dengan perbedaan yang signifikan. Hasil analisis Chi-Square Test terhadap pola ruga palatal terlihat pada tabel 8 dapat disimpulkan bahwa tidak terdapat hubungan antara pola ruga palatal dengan jenis kelamin.

Hasil penelitian ini sesuai dengan penelitian Abdellatif et al. (2011) yang melaporkan tidak ada perbedaan yang signifikan antara kedua jenis kelamin dalam pola ruga palatal di kalangan penduduk Mesir. Hasil yang sama juga dilaporkan pada penelitian sebelumnya terhadap populasi lain seperti populasi Australia (Santos et al., 2011). Berbeda dengan penelitian Shetty et al. (2011) pada populasi Mangalore di India dan Manjunath et al. (2012) pada populasi Manipal di India yang menemukan perbedaan signifikan antara kedua jenis kelamin dalam pola ruga palatal. Ruga palatal bentuk kurva dan lurus ditemukan lebih banyak pada wanita, sedangkan bentuk bergelombang dan lurus lebih banyak ditemukan pada pria. Perbedaan hasil ini mungkin dipengaruhi karena perbedaan populasi yang digunakan pada penelitian.

Secara embriologi ruga palatal terbentuk secara sempurna pada bulan ke 3 perkembangan intrauterin berasal dari jaringan ikat yang menutupi proses pembentukan palatina pada tulang maksila. Ruga palatal berkembang sebagai daerah proliferasi dan penebalan epitel mesenkimal selama awal kehidupan intrauterine bahkan sebelum elevasi palatal shelves. Bentuk ruga palatal diatur oleh serat inti yang berjalan anteroposterior dalam lingkaran konsentris pada masingmasing ruga. Oleh karena itu, ruga palatal menonjol menempati sebagian besar panjang dari palatal shelves pada waktu elevasi saat embrio. Proses ini diyakini akan terpengaruh oleh gen selama embriogenesis dan pertumbuhan postnatal yang dapat mengakibatkan perbedaan pola ruga antara populasi yang berbeda (Pantalacci et al., 2008).

Fibroblas dan serat kolagen terakumulasi dalam jaringan ikat di bawah epitel yang menebal dan membuat bentuk ruga palatal menjadi jelas. Inti atau bagian tengah pada ruga palatal manusia mengandung unsurunsur yang diyakini berkontribusi pada pemeliharaan bentuknya. Elemen struktur utama ruga mengandung glikosaminoglikan yang sifatnya hidrofilik menyebabkan jaringan membengkak dan memberikan kontribusi untuk pemeliharaan bentuk ruga sepanjang hidup (Nayak et al., 2007, Venegas et al., 2009).

Klasifikasi ruga palatal dari Thomas dan Kotze meliputi panjang, bentuk, dan unifikasi. Pada penelitian ini, peneliti hanya meneliti bentuk dari pola ruga palatal, sedangkan unifikasi ruga palatal tidak diteliti. Saraf et al. (2011) mengungkapkan bahwa kekuatan penentuan jenis kelamin mungkin lebih tinggi ketika unifikasi ruga palatal digunakan. Hasil penelitian Saraf et al. (2011) pada populasi India dan Fahmi et al. (2001) pada populasi Arab menunjukkan jenis unifikasi konvergen ditemukan secara signifikan lebih banyak pada wanita. Babu et al. (2013) pada penelitiannya di India melaporkan konvergen lebih banyak ditemukan pada pria, sedangkan divergen lebih banyak pada wanita.

Dalam pemeriksaan sidik bibir (cheiloscopy), anatomi bibir termasuk ketebalan dan posisi juga harus dianalisa. Posisi bibir bisa horisontal, elevated, atau depressed. Berdasarkan ketebalannya, bibir dibagi menjadi empat jenis yaitu bibir tipis (biasanya terlihat pada ras Kaukasoid di Eropa), bibir menengah $(8-10 \mathrm{~mm}$, jenis yang paling umum), bibir tebal atau sangat tebal (sering terlihat di Afrika dan Amerika), dan campuran (Caldas et al., 2007). 


\section{KESIMPULAN DAN SARAN}

Kesimpulan dari penelitian ini meliputi :

1. Reliabilitas pola sidik bibir lebih tinggi daripada reliabilitas pola ruga palatal dalam penentuan jenis kelamin pada mahasiswa Kedokteran Gigi Universitas Airlangga.

2. Terdapat hubungan antara pola sidik bibir dengan jenis kelamin.

3. Tidak terdapat hubungan antara pola ruga palatal dengan jenis kelamin.

Saran dari penelitian ini meliputi :

1. Diperlukan penelitian lanjutan dalam pemeriksaan sidik bibir yang meliputi anatomi bibir termasuk ketebalan dan posisi.

2. Diperlukan penelitian lanjutan dengan menganalisa unifikasi ruga palatal dalam pemeriksaan pola ruga palatal.

3. Diperlukan penelitian lanjutan pemeriksaan pola sidik bibir dan pola ruga palatal dengan metode pengambilan yang berbeda dan atau pada sampel yang lebih banyak.

\section{UCAPAN TERIMA KASIH}

1. Dr. Susy Kristiani, drg., M.Kes, selaku pembimbing utama yang telah menyediakan waktu, tenaga, dan pikiran untuk mengarahkan saya dalam penyusunan Tesis ini. Terima kasih untuk semangatnya.

2. Prof.Dr.Mieke Sylvia, MAR,drg.,MS.,Sp.Ort, selaku pembimbing serta yang telah menyediakan waktu, tenaga, dan pikiran untuk mengarahkan saya dalam penyusunan Tesis ini. Terima kasih untuk semangatnya.

3. Dr. Ahmad Yudianto, dr.,Sp.F.,M.Kes.,SH, selaku koordinator program studi Ilmu Forensik yang telah banyak membantu selama proses perkuliahan hingga penyusunan Tesis.

4. Adi Hapsoro, drg.,MS, yang telah membantu dalam penghitungan sampel penelitian. Terima kasih atas saran-sarannya.

5. Para dosen penguji yang telah memberikan saran-saran sehingga Tesis ini dapat terselesaikan dengan baik.

6. Bapak Hermadi dan Ibu Iflacha Ulfa selaku orang tua, serta kakak saya Ike Hervin Caprina,dr. yang banyak memberikan dukungan moral dan selalu mendoakan.

7. Suami saya tercinta, Wisnu Yuwandono, S.T. atas segala semangat, dukungan, kesabaran, dan perhatiannya selama ini sehingga saya bisa menyelesaikan studi S2 ini tepat waktu walaupun harus terpisah jarak.

8. Semua dosen dan $\mathrm{Bu}$ Emmy di Departemen Odontologi Forensik Fakultas Kedokteran Gigi Universitas Airlangga atas bantuan dan pengertiannya selama menyelesaikan penelitian.

9. Sahabat-sahabat saya, Dian Novita,drg., Ellyta Cendrasari,drg., Yessica Nainggolan,drg., Siti Umayasari,drg. yang telah banyak membantu.

10. Teman-teman seperjuangan, Astika Swastirani,drg. yang telah bersedia membantu dalam proses penelitian. Azmi, Tiara, Maria, Diana, Puni, Coco, Kiki, Desi, Reno, Rizka, Faizal, Basma terimakasih atas bantuan dan semangatnya.

\section{DAFTAR PUSTAKA}

Abdellatif, A.M., Awad, S.M., Hammad, S.M., 2011. "Comparative Study of Palatal Rugae Shape in Two Samples of Egyptian and Saudi Children." Pediatric Dental Journal, 21(2), 123-8.

Atmaji, M., Yun,i M., Atmadja, D., 2013. "Metode Pengambilan Sidik Bibir untuk Kepentingan Identifikasi Individu." Jurnal PDGI, 62(3), 64-70.

Augustine, J., Barpande, S.R., Tupkari, J.V., 2008. "Cheiloscopy as an Adjunct to Forensic Identification: A study of 600 
Individuals." $\quad J \quad$ Forensic Odontostomatol, 26, 44-52.

Azab, S.M.S., Magdy, R., 2015. "Patterns of Palatal Rugae Among Adult Egyptian Population." Journal of Forensic Sciences.

Babu, G.S., Bharath, T.S., Kumar, N.G., 2013. "Characteristics of Palatal Rugae Patterns in West Godavari Population of India." Journal Clinical Diagnostic, 7(10), 2356-9.

Bharath, S.T., Kumar, G.R., Dhanapal, R., Saraswathi, T.R., 2011. "Sex Determination by Discriminant Function Analysis of Palatal Rugae from a Population of Coastal Andhra." $J$ Forensic Dent Sci, 3(2), 58-62.

Byatnal, A., Kiran, A.R., Samata, Y., Guruprasad, Y., Telagi, N., 2014. "Palatoscopy: An Adjunct to Forensic Odontology: A Comparative Study Among Five Different Populations of India." J Nat Sci Biol Med, 5(1), 52-55.

Caldas, I.M., Magalhaes, T., Afonso A., 2007. "Establishing Identity Using Cheiloscopy and Palatoscopy." Forensic Science International, 165 (1), $1-9$.

Devi, A., Astekar, M., Kumar, V., Kaur, P., Singh, N., 2015. "The Study of Inheritance Analysis and Evaluation of Lip Prints in Individuals." Journal of Forensic Dental Sciences, 7(1), 49-53.

Dineshshankar, J., Ganapathi, N., Yoithapprabhunath, T.R., Maheswaran, T., Kumar, M.S., Aravindhan, R., 2013. "Lip Prints: Role in Forensic Odontology." J Pharm Bioallied Sci, 5(1), 95-97.

Dongarwar, G.R., Bhowate, R.R., Degwekar, S.S., 2013. "Cheiloscopy-Method of Person Identification and Sex Determination." Open Access Scientific Reports, 2(1).

Fahmi, F.M., Al-Shamrani, S.A., Talic, Y.F., 2001. "Rugae Pattern in a Saudi Population Sample of Males and Females." SDJ, 13, 92-5.

Gondivkar, S.M., Indurka, R.A., Degwekar, S., Bhowate, R., 2009. "Cheiloscopy for
Sex Determination." $J$ of Forensic Dental Sci, 1(2), 56-60.

Gordon, R.W., 2010. "Age Grouping to Optimize Augmentation Success." Dent Today, 29, 128-31.

Indira, A.P., Gupta, M., David, M.P., 2012. "Palatal Rugae Patterns for Establishing Individuality." Journal of Forensic Dental Sciences, 4(1), 2-5.

Kapoor, N., Badiye, A., 2015. "A Study of Distribution, Sex Differences and Stability of Lip Print Patterns in an Indian Population." Saudi Journal of Biological Sciences.

Kaul, R., Padmashree, S.M., Shilpa, P.S., Sultana, N., Bhat, S., 2015. "Cheiloscopic Patterns in Indian Population and Their Efficacy in Sex Determination: A Randomized CrossSectional Study." J Forensic Dent Sci, 7(2), 101-106.

Kautilya, V., Bodkha, P., Rajamohan, N., 2013. "Efficacy of Cheiloscopy in Determination of Sex Among South Indians." Journal of Clinical and Diagnostic Research, 7(10), 2193-2196.

Kavitha, B., Einstein, A., Sivapathasundharam, B., Saraswathi, T.R., 2009. "Limitations in Forensic Odontology." Journal of Forensic Dental Sciences, 1(1), 8-10.

Leveque, J.L., Goubanova, E., 2004. "Influence of Age on the Lips and Perioral Skin." Dermatology, 208, 30713.

Malik, R., Goel, S., 2011. "Cheiloscopy : A Deterministic Aid for Forensic Sex Determination." Journal of Indian Academy of Oral Medicine and Radiology. 23(1), 17-19.

Manjunath S., Bakkannavar S.M., Kumar P.G., Bhat V.J., Prabhu N., Asha Kamath A. (2012). Palatal rugae patterns among the Indians at Manipal, India. JPBMS, 20(10), 1-5.

Mishra, P., Gupta, M., Singh, N., Shrivastava, K., Singh, P., Mishra, R., 2015. "An Overview of Chelioscopy \& Palatoscopy: An Aid in Forensic 
Investigation." International Journal of Nursing Didactics, 5, 6.

Mustafa, A.G., Allouh, M.Z., Alshehab, R.M., 2015. "Morphological Changes in Palatal Rugae Patterns Following Orthodontic Treatment." Journal of Forensic and Legal Medicine, 31, 1922.

Nagalaxmi, V., Ugrappa, S., Jyothi, N., Latitha, C.H., Molot, K.N., Kodangal, S., 2014. "Cheiloscopy, Palatoscopy and Odontometrics in Sex Prediction and Discrimination- a Comparative Study." The Open Dentistry Journal, 8, 269-279.

Nayak, P., Acharya, A.B., Padmini, A.T., Kaveri, H., 2007. "Differences in the palatal rugae shape in two populations of India." Arch Oral Biol, 52, 977-82.

Pantalacci, S., Prochazka, J., Martin, A., Rothova, M., Lambert, A., Bernard, L., 2008. "Patterning of Palatal Rugae Through Sequential Addition Reveals an Anterior/Posterior Boundary in Palatal Development." BMC Dev Biol, 8, 1-40.

Patel, S., IshPaul, Madhusudan, A.S., Ramesh, G., Sowmya, G.V., 2010. "A study of lip prints in relation to gender, family, blood group." International Journal of Oral and Maxillofacial Pathology, 1(1), 4-7.

Prabhu, R.V., Dinkar, A.D., Prabhu, V.D., Rao, P.K., 2012. "Cheiloscopy: Revisited." J Forensic Dent Sci, 4(1),47-52.

Prawestiningtyas, E., Algozi, A.M., 2009. "Identifikasi Forensik Berdasarkan Pemeriksaan Primer dan Sekunder Sebagai Penentu Identitas Korban pada Dua Kasus Bencana Massal." Jurnal Kedokteran Brawijaya, Vol XXV, No. 2.

Rai, B., Kaur, J. 2013. Evidence-Based Forensic Dentistry. New York : Springer.

Rajan, V.P., John, J.B., Stalin, A., Priya, G., Abuthagir, A.K., 2013. "Morphology of Palatal Rugae Patterns Among 5-15 Years Old Children." Journal of
Pharmacy and BioAllied Sciences, 5(1), 43-47.

Randhawa, K., Narang, R.S., Arora, P.C., 2011. "Study of The Effect of Age Changes on Lip Print Pattern and Its Reliability in Sex Determination."'J Forensic Odontostomatol, 29(2), 45-51.

Reddy, V.K., 2011. "Lip prints: An Overview in Forensic Dentistry." Journal of Advanced Dental Research, 2(1), 17-20.

Rohit, M., Sumit, G., 2011. "Cheiloscopy: A Deterministic Aid for Forensic Sex Determination." J Ind Acad Oral Med Radiol, 23, 17-9.

Rotzsher, K., 2014. Forensic and Legal Dentistry. Springer, Germany, pp 226, 317.

Santos C., Caldas M. (2012). Palatal rugae pattern in a Portuguese population: a preliminary analysis. J Forensic Sci, 57(3), 786-8.

Saraf, A., Bedia, S., Indurkar, A., Degwekar, S., Bhowate, R., 2011. "Rugae Pattern as An Adjunct to Sex Differentiation in Forensic Identification." J Forensic Odontostomatol, 29(1), 14-19.

Senn, D.R., Weems, R.A. 2013. Manual of Forensic Odontology. New York : Taylor and Francis Group.

Sharma, P., Saxena, S., Rathod, V., 2009. "Comparative Reliability of Cheiloscopy and Palatoscopy in Human Identification." Indian J Dent Res, 20(4), 453-7.

Shetty M., Premalatha K. (2011). Study of palatal rugae pattern among the student population in Mangalore. J Indian Acad Forensic Med, 33(2), 112-5.

Sivapathasundharam, B., Prakash, P.A., Sivakumar, G., 2001. "Lip Prints (Cheiloscopy)." Indian Dent Res, 12, 234-237.

Vahanwala, S., Nayak, C.D., Pagare, S.S., 2005. "Study of lip prints as aid for sex determination." Medico - Legal Update, 5, 93-8.

Vats, Y., Dhall, J.K., Kapoor, A.K., 2012. "Gender Variation in Morphological Patterns of Lip Prints Among some 
Jurnal Biosains Pascasarjana Vol. 17 (2015) pp

(C) (2015) Program Pascasarjana Universitas Airlangga, Indonesia

North Indian Populations." J Forensic Dent Sci, 4(1), 19-23.

Venegas, V.H., Valenzuela, J.S., Lopez, M.C., Galdames, I.C., 2009. "Palatal Rugae: Systematic analysis of its shape and dimensions for use in human identification." Int J Morphol, 27, 81925. 